Uşak Üniversitesi Sosyal Bilimler Dergisi (2010) 3/2, 136-157

\title{
Tekstil Sektöründe Endüstri-içi Ticareti Etkileyen Faktörler Üzerine Ampirik Çalışma
}

\section{Hilmi ÖZKAYA*}

Özet

Yatay endüstri-içi ticaret ve dikey endüstri-içi ticaret ayrımının dikkate alındığı çalışmada, 1989-2009 döneminde, Türkiye'nin tekstil sektöründeki endüstri-içi ticaretle ilgili gelişmeler ortaya konularak, endüstri-içi ticareti etkileyen faktörleri tespit etmek amaciyla ülkeye ve sektöre özgü belirleyicileri esas alan regresyon analizi yapılmıştır. $\mathrm{Bu}$ analize göre kişi başına düşen gelir ve ölçek ekonomileri tekstil sektöründe endüstri-içi ticaret düzeyini olumlu etkilerken, doğrudan yabancı yatırım olumsuz etkilemektedir.

Anahtar Kelimeler: Endüstri-içi Ticaret, GL Endeks, Yatay Endüstri-içi Ticaret, Dikey Endüstri-içi Ticaret.

\section{An Empirical Study on the Factors Influencing Intra-Industry Trade in Textile Sector}

\begin{abstract}
In this study where is considering discrimination of horizantal intraindustry trade and vertical intra-industry trade, in period 1989-2009, exerting the developments related intra-industry trade in Turkey's textile sector in order to determine the factors influencing intra-industry trade the regression analysis is made based on the determinants the country characteristics and industry characteristics. According to this analysis, while per capita income and scale economies influence positively the level of intra-industry trade in textile sector, foreign direct investment influence negatively.
\end{abstract}

Keywords: Intra-industry trade, GL Index, Horizantal Intra-Industry Trade, Vertical Intra-Industry Trade.

\section{Giriş}

Küreselleşmenin yoğun biçimde yaşandığı son dönemde uluslararası alandaki gelişmeler, diş ticaret teorilerinin temel varsayımlarının değişmesine yol açmıştır: Ölçeğe göre sabit getiri durumu, ölçeğe göre artan getiri durumuyla, tam rekabetçi piyasa koşulları eksik rekabet piyasa koşullarıyla ikame edilmiştir. Teknolojinin yanı sıra birtakım değişimlerin etkisiyle ülkelerin uzmanlaşma biçimi, faktör donatımları veya karşılaştırmalı üstünlükleri esas almamaktadır. Ülkeler, bir endüstri grubuna ait malları hem ihraç hem ithal edebilmektedirler. Bir başka deyişle,

* Yrd. Doç. Dr., Uşak Üniversitesi İktisadi ve İdari Bilimler Fakültesi 
endüstriler arası ticaret yerini endüstri-içi ticarete bırakmıştır. Böylece dış ticaret ve diş ticaretten elde edilen kazançlar monopolcü rekabet piyasa koşulları tarafindan belirlenmektedir (Yılmaz,1992: 219).

Endüstriler arası ticareti konu alan klasik dış ticaret teorilerinin 2. Dünya Savaşı sonrasında uluslararası ticaretin yapısı ve boyutunda görülen değişimlerin değerlendirilmesinde yetersiz kalması, bu husustaki eksiklikleri gidermeye yönelik yeni yaklaşımların ortaya çıkmasına yol açarak EITT konusunda teorik çalışmaları teşvik etmiştir (Çakmak, 2006: 33). Büyük ölçüde eksik rekabet, ürün farklılaştırması ve ölçek ekonomilerini esas alan dış ticarette yeni yaklaşımlar, EİT ticaretin yapısını açıklamaya yöneliktir. EIT, benzer yapılara sahip ülkeler arasında aynı endüstriye ait bir malın ithalat ve ihracatının yapılması biçiminde şekillenen bir ticaret türüdür (Rivera Batiz ve Oliva, 2003: 39). Başka bir deyişle EİT, aynı endüstri grubuna giren malların eş zamanlı ihracat ve ithalatı olarak ifade edilmektedir (Çakmak, 2006: 33).

Geleneksel dış ticaret kuramlarından Faktör donatımları kuramı, ülkelerin birbirlerine benzerliği ne kadar az ise ülkeler arasında o kadar fazla ticaret olacağını ifade etmektedir. Ancak Verdoorn (1960), Balassa $(1963,1966)$ ve Grubel (1967) gibi araştırmacılar, endüstriyel yapıları ve talep koşulları bakımından birbirlerine benzeyen ülkeler arasında sanayi malları ticaretinin yüksek düzeyde olduğu ve bu ticaretin önemli oranını da EİT oluşturduğunu ortaya koymuşlardır. 1960'lı ve sonraki yıllar EİT üzerine çalışmaların arttı̆̆ 1 dönemdir. Bu öncü çalışmalar, EİT'nin gelişmiş ülkeler arasındaki ticaretin önemli oranda olduğunu gösteren ve sonraki çalışmaların temel kaynağını teşkil eden Grubel ve Lloyd (1975) çalışmasının ortaya çıkmasına yol açmıştır (Şimşek, 2005: 43-44).

EİT bağlamında ilk kapsamlı çalışma Grubel ve Lloyd tarafindan yapılmıştır. Bu çalı̧̧mada EİT endeksi geliştirilmiş ve söz konusu endeks değerinin birçok ülkede yüksek düzeyde olduğu görülmüştür (Kaya ve Atış, 2007: 252). Bu çalışmadan sonra 1980'li yıllarda Krugman (1979), Lancester (1980) ve Helpman (1981) gibi birçok araştırmacının söz konusu konu üzerinde yoğunlaştığı görülmektedir. Bu araştırmacılar yeni dış ticaret yapısını açıklamaya yönelik monopolistik rekabet modeli aracılığıyla EİT yaklaşımını geliştirmişlerdir. Yaklaşımın temelinde üretimde artan getiri ve ürün farklılaştırması vardır. Krugman'a göre EİT'nin temelinde ölçek ekonomileri yatmaktadır, bu da bir endüstri içinde farklı malların üretilmesine neden olarak uzmanlaşma ve dış ticareti arttırmaktadır (Krugman, 1981: 960).

Özellikle 1960'l1 yıllarda Endüstri-içi ticaret (EİT) kavramının uluslararası iktisat yazınına girişinden bu yana, bu tür ticareti açıklamaya yönelik birçok teorik ve ampirik çalışmalar artarak yapıla gelmiş ve aynı zamanda dış ticaret politikalarının oluşturulmasında önemli etkiler 
oluşturmuştur. Greenway ve Milner (1986) ve Greenway ve Torstensson (1997) ifade ettikleri gibi endüstri-içi ticarete teorik ve ampirik ilgi, son 40 yıldır hızla artarak devam etmektedir.

EİT' nin oranının ölçümü ve EİT' yi iyi ölçebilecek endeksin geliştirilmesine yönelik çalişmalar, endüstrilerde geçerli olan mal farklılaştırmasına bağlı olarak EİT' yi yatay endüstri-içi ticaret (YEİT) ve dikey endüstri-içi (DEİT) biçiminde ayırmanın gerekliliğinin olup olmadığ 1 konusunda tartışmaları beraberinde getirmiştir. $\mathrm{Bu}$ tartışmalara yol açan neden, bir endüstrideki mallar yatay biçimde farklılaşmışsa, EİT bağlamında söylenenler kabul edilirken, bir endüstride dikey mal farklılaştırması varsa, EİT' nin yapısının tekrar incelenmesi zorunluluğunun ortaya çıkmasıdır. $\mathrm{Bu}$ arada malların model, renk, desen vb. bakımından farklıklaşması, yatay farklılaşma, malların kalitesinin farklı olması malların dikey farklılaşması anlamını taşımaktadır. Dolayısıyla DEIT, ticaretin ara şekli olarak gösterilmekte ve ülkeler arasında aynı malın çeşitlerinin üretimi ve ticaretinin yapılmasına karşın mal çeşitlerinin üretiminde karşılaştırmalı üstünlük sağlanacak biçimde farklı olduğu belirtilmektedir (Şimşek, 2005: 44).

Geleneksel olarak EIT, sadece gelişmişlik düzeyleri benzer ülkeler arasında olabileceği düşünülürken, dikey farklılaşmanın literatüre kazandırılmasıyla birlikte DEIT, daha çok gelişmiş ülkelerle gelişmekte olan ülkeler arasındaki ticareti, YEİT ise daha çok gelişmiş ülkelerin kendi aralarındaki ticareti ifade etmek amacıyla kullanılmaktadır (Şimşek, 2005: 44). $\mathrm{Bu}$ çalışmada, Türkiye gibi gelişmekte olan ülkelerdeki EİT çalışmalarında söz konusu ayrımın göz önünde bulundurulmasının önem taşıması nedeniyle, tekstil sektöründeki EİT' nin payı DEITT-YEİT bakımından analiz edilmektedir. Bu ayrımın yapılmaması, önemli orandaki DEIT' nin dikkate alınmaması nedeniyle sonuçların yanlış yorumlanmasına yol açabilecektir.

\section{Literatür İncelemesi}

EITT kavramının giderek önem kazandığı bir dönemde Türkiye'nin gerek makro temelde gerekse özellikle endüstri temelinde ticaret yapısının bu değişimden etkilenip etkilenmediğine ilişkin bazı çalışmalar mevcuttur. Çepni ve Köse (2000) tarafından yapılan araştırma bu bağlamda yapılan öncü çalışmalardandır. 1989-1999 dönemindeki Avrupa Birliği (AB) ve OECD ülkeleri ile Türkiye arasındaki EİT' yi hesaplayan çalışma, AB ülkeleriyle Türkiye arasındaki EİT oranının diğer ülkelere nispeten daha yüksek olduğunu göstermektedir.

Erk ve Tekgül (2001) tarafından yapılan başka bir araştırmada, 1993-1998 dönemi Türkiye ile $\mathrm{AB}$ arasında ticarete konu olan 97 ürün grubunun EİT ve yatay-dikey farklılaşma düzeyleri tespit edilmiştir. Buna göre, Türkiye ve $\mathrm{AB}$ arasındaki ticaretin karşılaştırmalı üstünlüklere 
dayanmasının yanı sıra önemli bir kısmının EİT yapısında dikey mal farklılaştırmasının olduğu ifade edilmektedir.

Doğaner (2001a) tarafindan yapılan araştırmalardan biri 1992-1997 arası Türkiye'nin $\mathrm{AB}$ ve Türkî Cumhuriyetleri ile yaptığı ticaretin yapısını belirleme amacını taşımaktadır. Bu araştırmanın sonuçları, Türkiye' nin ilgili ülkelerle olan ticaretinin genel anlamda EAT biçiminde gerçekleştiğini ortaya koymaktadır.

Diğer araştırma (2001b) ise, Türkiye'nin tekstil sektöründeki karşılaştırmalı üstünlüğün EİT bakımından da geçerli olup olmadığı tespit etme amacını taşımaktadır. 1990-1997 dönemi SITC Rev.3 verileri yardımıla standart G-L ve marjinal endüstri-içi ticaret endeksleri hesaplanan araştırmada, alt ürün grupları itibarıyla çoğunluğu, özellikle de sentetik dokumanın söz konusu dönemde yüksek EİT düzeyine sahip olduğu ifade edilmektedir.

Bir başka araştırma da Türkiye'nin $\mathrm{AB}, \mathrm{AB}$ dışı ülkeler ve bir bütün olarak Dünya ülkeleri arasındaki EİT' nin hesaplanması ve EİT' yi belirleyen temel etkenlerin göz önüne alınarak Türkiye'nin EİT' nin açıklanması amaçlarıyla Küçükahmetoğlu (2002) tarafından yapılmıştır. 1989-1998 dönemi, SITC Rev.3 kapsamındaki üç basamaklı ürün grubundaki ithalat ve ihracat verileri ve standart G-L endeksinin kullanıldığ söz konusu araştırmanın bulgularına göre, Türkiye'nin EITT'i nispi olarak düşük düzeydedir ve Türkiye' nin $\mathrm{AB}$ ülkeleri ile ticaretini zamanla serbestleştirmesi ve daha sonra Gümrük Birliği yoluyla iktisadi bütünleşmeyi gerçekleştirmesi bu ülkelerle olan EİT'nin artmasına yardımcı olmuştur. Bunun yanında bu araştırma, Türkiye'nin EİT düzeyinin gelişmiş ülkelere nazaran daha düşük olduğunu buna karşılık yeni sanayileşen ülkelere daha yakın düzeyde olduğunu ve söz konusu analiz döneminde Türkiye'de fert başına düşen gelir seviyesi ile EİT düzeyinin genel olarak aynı yönde gelişme gösterdiklerini ortaya koymaktadır.

Erlat ve Erlat (2003) tarafindan yapılan araştırma, 1969-1999 dönemi, SITC Rev.3'e göre 3 basamaklı sektörel verilerle, 15 AB üye ülkeyi kapsayan dünya ticareti ile Türkiye'nin EİT'nin statik ve dinamik yapısını analiz etmiştir. Buna göre genel anlamda ticaretin EAT özelliğe sahip olduğu ve bu özelliğin 1980 sonrası dönemde sınırlı olarak EİT’ye dönüştüğü belirlenmektedir.

Bu konuyla alakalı başka bir araştırma Yenilmez ve Kutlu (2005) tarafından yapılmıştır. 1981-2001 dönemini ele alan ve söz konusu dönemi GB öncesi ve sonrası biçiminde sınıflandıran bu araştırma, Türkiye ve AB ülkeleri arasında SITC Rev. 3, 5 basamaklı ürün gruplarında standart G-L endeksi kullanarak ülkeleri analiz etmektedir. Buna göre GB, ülkelerin EITT düzeylerinde ve ticarete konu olan ürün çeşidi sayısında artışa yol 
açmaktadır. Özellikle otomotiv yan sanayi ve tekstil ürünlerinde Türkiye'nin $\mathrm{AB}$ ülkeleriyle EITT düzeyinin yüksek olduğunu vurgulamaktadır.

Bu konuya ilişkin başka bir Şimşek (2005) tarafından, 1992-2003 y1llarında Türkiye'nin dünyayla, tüm olarak OECD ile ve iki yönlü olarak OECD ülkeleri ile ticareti için SITC Rev.3 verileri kullanılarak yapılan başka bir çalışmada iki yönlü ticaret endeksi kullanılmış, sonrasında birim değer farklılı̆̆ 1 temelinde yatay ve dikey endüstri-içi dış ticaret ayrımı yapılmıştır. $\mathrm{Bu}$ çalışmanın bulgularına göre, Türkiye'nin endüstri-içi dış ticaret içinde daha çok düşük kalite dikey endüstri-içi dış ticaretin hâkim olduğu belirtilmektedir.

Türkiye ile Almanya, İtalya, Fransa ve İngiltere arasında imalat endüstrisi dış ticaretinde EİT' nin yapısını ve önemini tespit etmek amacıyla 1991-2004 döneminde SITC Rev. 3, 3 basamaklı ürün grupları verileri ve standart G-L endeksi kullanılarak Çakmak (2006) tarafindan bir araştırma yapılmıştır. Buna göre, ilgili dönemde Türkiye ile dört ülke arasındaki EİT oranlarını temel alan sıralamanın zamanla çok değiştiği, söz konusu dönemin başlarında Türkiye ile imalat endüstrisi EİT düzeyi en yüksek ülkeler sırasıyla İngiltere, İtalya, Almanya ve Fransa iken, dönemin sonlarına doğru bu siralama Fransa, İtalya, Almanya ve İngiltere biçiminde olduğu ifade edilmektedir.

Kaya ve Atış (2007) tarafindan yapılan çalışma, Türkiye'nin kimya sanayi ürünleri ithalat ve ihracatında öne çıkan ülkeler ile EITT'nin gelişimini araştırma amacını taşımaktadır. Bu çalışma, Türkiye ile belli başlı AB üyesi ve AB'ye aday ülkeler arasında 1990-2005 dönemi ve SITC Rev.3'e göre 5 basamaklı kimya sanayi ürün grubuna ait verilerle, standart G-L endeksi kullanarak statik analiz, daha sonra Brülhart'nn marjinal EIT ticareti belirlemeye yönelik A ve B endeksleri kullanarak dinamik analiz gerçekleştirmektedir. Buna göre, Türkiye'nin kimya sanayi EITT düzeyi genel olarak sektör tüketiminin dışa bağımlı olması nedeniyle düşük seviyededir. Araştırmanın bulgularına göre, son yıllarda bazı alt ürün gruplarındaki söz konusu ticaret, ticaretin serbestleştirilmesiyle birlikte artan ticaret ilişkileri ve zamanla yalnızca ihracatçı ya da ithalatçı olunan ürün gruplarında çift yönlü ticaret yapısına dönüşüm nedenleriyle EİT'e yönelmektedir.

1989-2005 dönemindeki Türkiye'nin EİT'ni ve ülkeye özgü belirleyicilerini araştırmak amacıyla Aydın (2008) tarafindan yapılan çalışmada, Türkiye'nin EİT oranının \% 40 düzeyinde olduğu ve bu dönemdeki dış ticaret gelişmelerinin karşılaştırmalı üstünlüklere göre gerçekleştiği ifade edilmektedir. Bunun yanı sıra bu çalışma, tüm endüstriler bakımından EİT'nin önemli ülkeye özgü belirleyicilerin ülkenin ticaret ortakları ile arasındaki ticari dengesizlik, kalkınma düzeyi ve dışa açıklık farklılıkları olduğunu ve söz konusu belirleyiciler ile EITT arasındaki ilişkinin negatif yönlü olduğunu belirtmektedir. Öte yandan söz konusu çalışmada, Türkiye ile ticaret ortakları arasındaki coğrafi uzaklık arttığında EITT 
oranlarının düş̧üğü, $\mathrm{AB}$ ile Gümrük Birliği ve doğrudan yabancı yatırım girişleri ile EITT arasında pozitif ilişkinin görüldüğü vurgulanmaktadır.

EİT'nin Türkiye- AB ticaretindeki önemini vurgulamak ve Türkiye-AB ticaretinde EİT olgusunu genel ve sektörel temelde analiz etmek amacıyla Çalışkan (2010) tarafından bir araştırma yapılmıştır. Bu araştırma, SITC 3 basamak düzeyi ticaret verileriyle 1990-2007 dönemi için Türkiye$\mathrm{AB}$ ticaretinde EITT düzeyini hesaplamaktadır. Araştırmanın bulgularına göre, Türkiye- $\mathrm{AB}$ arasında gerçekleşen ticaretin kayda değer bir oranı EITT türündedir. Öte yandan yine araştırmaya göre, 1990-2007 yılları arasında EİT düzeyi istikrarlı bir şekilde artış göstermekle birlikte Türkiye'nin AB ile dış ticareti halen ağırlıklı olarak EAT yapısı biçimindedir.

$\mathrm{Bu}$ çalışmanın amac1, Türkiye tekstil sektörü endüstri-içi ticaret düzeyindeki gelişmeleri ortaya koymak ve sektördeki endüstri-içi ticareti etkileyen faktörleri belirlemektir. Bu amaç çerçevesinde 1989-2009 döneminde, Standart International Trade Classification -SITC (Rev 3 ) 3 basamaklı ürün grubu düzeyinde tekstil sektörü alt gruplarında endüstri-içi ticaret düzeyleri hesaplanmıştır. Endüstri-içi ticaret oranları hesaplanırken, literatürde çok tercih edilen düzeltilmemiş (klasik) Grubel-Lloyd endeksinin ağırlandırılmamış ortalamaları kullanılmıştır. İkinci aşamada tekstil sektöründeki endüstri-içi ticaretin yatay ya da dikey olduğu \% 25 eşik düzeyi kullanılarak tespit edilmiştir. Bu ayrıştırma Türkiye'nin tekstil sektörünün sektörel bazda gelişmiş ülkeler seviyesine kıyasla durumunu ortaya koyma veya sektörün rekabet gücünü genel olarak belirlemesi bakımından önem taşımaktadır. Son aşamada tekstil sektöründeki endüstri-içi ticareti etkiyen faktörleri belirlemek üzere ülkeye ve sektöre özgü belirleyicileri dikkate alan regresyon analizi yapılmıştır. $\mathrm{Bu}$ araştırmanın tekstil endüstrisinin EITT düzeyini tespit ederken yatay ve dikey EIT ayrışmasını dikkate alması ve EITT'yi etkileyen faktörleri belirlemeye yönelik regresyon analizini ortaya koyması, araştırmayı mevcut çalışmalardan farklı kılmaktadır.

\section{Endüstri-İçi Ticaretin Ölçülmesi}

Uygulamalı olarak EİT düzeyini tahmin etmede geliştirilen çeşitli ölçütler vardır. En yaygın kullanılan ölçüt Grubel-Lloyd endeksidir. Bu endeks aşağıda verilmiştir (Grubel ve Lloyd, 1971; 497; Greenaway ve Milner, 1986; 62);

$$
E \dot{I} T_{i}=1-\frac{\left|X_{i}-M_{i}\right|}{X_{i}+M_{i}} \text { ya da } E \dot{I} T_{i}=\frac{\left(X_{i}+M_{i}\right)-\left|X_{i}-M_{i}\right|}{X_{i}+M_{i}}
$$

Eşitlikte, i, SITC ürün grubunu, $X$ ihracatı, $M$ ithalatı, $\left|X_{i}-M_{i}\right|$ ise EİT' yi belirtmektedir. Eşitliğin payı EİT' yi, geneli ise EİT' nin toplam ticarete oranını ortaya koymaktadır. $\mathrm{Bu}$ endeks yüzde biçimiyle de gösterilebilmektedir. 
Her bir endüstri grubu ihracatının, toplam ticarete oranının farklı olması nedeniyle, söz konusu endüstri grubuna ilişkin EITT derecesi hesaplanırken ağırlıklı ortalama belirleyici olmaktadır. Ağırlıklı ortalama EİT endeksi aşağıdaki biçimde formüle edilmiştir;

$$
\begin{aligned}
& E \dot{I} T_{i}=\frac{\sum_{i=1}^{i=n}\left(X_{i}+M_{i}\right)-\sum_{i=1}^{i=n}\left|X_{i}-M_{i}\right|}{\sum_{i=1}^{i=n}\left(X_{i}+M_{i}\right)} \\
& 0 \leq E \dot{I} T_{i} \leq 1 \text { ya da yüzde olarak } 0 \leq E \dot{I} T_{i} \leq 100 \text { olacaktır. }
\end{aligned}
$$

$E \dot{I} T_{i}$ Yukarıda ifade edildiği gibi, 0 ile 1 arasında değer almaktadır. Yüzde cinsinden 0 ile 100 arasında bir değer olacaktır. Bu çalışmada 0 ile 1 arasındaki değerin kullanılması tercih edilmektedir. Eğer bu değer 0 veya 0 'a yakınsa dış ticaretin yönü EAT; 1 veya 1'e yakınsa ilgili endüstri grubunda dış ticaretin EİT yönlü olduğunu ve ticarette uzmanlaşma gerçekleştiğini belirtmektedir.

Öte yandan EİT düzeyinin ölçümünde önemli gelişmeler olmasına rağmen, her bir endüstri için geçerli olan mal farklılaştırmasına bağlı olarak EITT'nin YEİT ve DEİT şeklinde ayrılması gerektiği yönünde öneriler ortaya çıkmaktadır. Bir endüstride üretilen malların yatay olarak farklılaşması, genel anlamda malların model, renk, desen vb bakımlardan farklılaştırılmasını ifade ederken, dikey farklılaştırma ise, malların kalite düzeyinin farklı olmasını göstermektedir. $\mathrm{Bu}$ bağlamda bir endüstride üretilen malların dikey veya yatay olarak farklılaşması, önem taşımaktadır. Yatay farklılaşma durumunda, EITT hususunda söylenenler kabul görmesine karşın, dikey mal farklılaşma durumunda EİT' nin yapısının yeniden ele alınması gerekliliği ortaya çıkmaktadır.

Geleneksel olarak EİT' nin gelişmişlik düzeyleri birbirine yakın ülkeler arasında olacağ1 düşünülürken, dikey farklılaşmanın ortaya çıkmasıyla bu düşüncenin de değişmesi gündeme gelmektedir. Bu çerçevede literatürde DEIT, daha çok gelişmiş ülkelerle gelişmekte olan ülkeler arasındaki ticareti (gelişmişlik düzeyi farklı olan ülkeler), YEİT ise daha çok gelişmiş ülkelerin kendi arasındaki ticareti ifade etmek için kullanılmaktadır (Şimşek, 2005:44). Bu çalışmanın tekstil endüstrisi EİT' ni yatay ve dikey biçimdeki ayrımı dikkate alarak analiz etmesi, endüstrinin ve kullandığ teknolojinin gelişimi, düzeyi ve rekabet gücü hakkında yorum getirebilmesi bakımlarından önem taşımaktadır.

Literatürde YEITT ve DEIT ölçümlerinde genel olarak standart Grubel-Lloyd endeksinin değişik türevleri kullanılmaktadır. Bu çalışmada GHM endeksi (Greenaway, Hine ve Milner, 1994, 1995) kullanılacaktır. Bu yaklaşım, yatay mal farklılaştırmasını ihracat birim değerlerinin ithalat birim değerlerine oranının belirlenen aralıkta olması biçiminde ifade etmektedir.

Buna göre, $1-a \leq \frac{U V_{x}}{U V_{m}} \leq 1+a$ ise, YEİT'yi gösterirken, eğer $\frac{U V_{x}}{U V_{m}}<1-a$ ya da $\frac{U V_{x}}{U V_{m}}>1+a$ ise, DEİT'yi göstermektedir. Buradaki 
formulasyonlarda $U V_{x}$ her malın ihracat birim değerini, $\mathrm{UV}_{\mathrm{m}}$ her malın ithalat birim değerini, $a$ eşik değeri ifade etmektedir.

Ayrıca bu çalışmada $\mathrm{P}_{\mathrm{x}}$ (FOB fiyatı) ve $\mathrm{P}_{\mathrm{m}}$ (CIF fiyatı) olarak yukarıdaki değerlerin yerine alınmıştır. Bunun yanında literatürde, yatay ve dikey mal farklılaştırması ayrımı için kullanılan eşik değerleri \% 15 ve \% 25 'tir. Çalışmada \% 25 eşik değeri kullanılmıştır. Çünkü gelişmekte olan ülkelerde eksik bilgi koşulları ve ticaret istatistiklerine dâhil edilen değerlerin reel kur dalgalanmalarından etkilenmeleri, \% 15 eşik değerinin dar kalma ihtimalini arttırmaktadır. Dolayısıyla $0,75 \leq \mathrm{P}_{\mathrm{x}} / \mathrm{P}_{\mathrm{m}} \leq 1,25$ durumu YEITT'yi gösterirken, $0<\mathrm{P}_{\mathrm{x}} / \mathrm{P}_{\mathrm{m}}<0,75$ veya $\mathrm{P}_{\mathrm{x}} / \mathrm{P}_{\mathrm{m}}>1,25$ durumu DEIT'yi belirtir. Bununla ilgili hesaplanmış veriler Tablo 3 'te verilmiştir.

\section{Türkiye'de Tekstil Endüstrisi Ve Endüstri-İçi Ticaret}

Türkiye'nin sanayileşmesi ve yoksulluğun azaltılması sürecinde önemli rol oynayan tekstil endüstrisi, pamuk, pamuklu iplik ve dokuma, yün, yünlü iplik ve dokuma, ipek, ipekli dokuma, sentetik iplik, sentetik dokuma, kord bezi, keten, kenevir ve bunlardan elde edilen mamullerin kullanıldı̆̆ hazır giyim ile el ve makine halıları alt sektörlerini kapsar. Başka bir ifadeyle tekstil, çeşitli lif çeşitlerinin ilk aşamada iplik haline getirilmesi sonrasında belirli desen ve renklerle birleştirilmesi yoluyla kumaş ve daha sonra da nihai ürün elde edilmesi aşamalarından oluşan üretim faaliyetidir (Çoban ve Kök, 2005: s. 69-70).

Geçmişi Osmanlı İmparatorluğuna uzanan Türk tekstil endüstrisi, Osmanlı döneminde pamuk ve iplik üretilmesi ve işlenmesi üretim faaliyetlerinin önemli bir bölümünü oluştururken, devletçilik politikasının uygulandığı cumhuriyet döneminin başlarında Sümerbank'ın kurulmasıyla birlikte gelişmeye başlamıştır. Beş yıllık kalkınma planlarının uygulamaya konulduğu planlı dönemde, ithal ikameci sanayileşme politikasına bağlı olarak bu sektöre yönelik teşvik uygulamaları sonucunda sektörde önemli kapasite artışları gerçekleşmiştir (Tan, 2001: s. 6). En temel hammadde olan pamuğun Türkiye'de önemli miktarda yetiştiriliyor olması, izleyen yıllarda sektörün gelişmesine yol açmıştır. 1950'li y1llarda tekstil sektöründe, 1970'li yılların başlarında hazır giyim sektöründe net ihracatçı durumuna gelen söz konusu endüstri, 1980'li yıllarda ihracat miktarında önemli miktarlara ulaşmıştır. Özellikle ihracata dayalı sanayileşme politikasıyla birlikte endüstride önemli atılım gerçeklemiş ve toplam üretiminin yarısından fazlası ihraç edilirken Türkiye'nin ihracat hacminde önemli pay elde ederek ekonominin lokomotifi konumuna gelmiştir. Nispeten ucuz emek, kaliteli hammadde ve fiyatların dünya fiyatlarının altında olması nedeniyle Türkiye tekstil endüstrisi, 1980'li yıllar ve sonrasında liberal dış ticaret politikalarından önemli oranda yarar sağlamıştır (Çoban ve Kök, 2005: s. 7172) . Kısaca, geçmişte Türkiye'de tekstil endüstrisi, dünyada gelişmekte olan 
ülkelerdekine paralel biçimde ilk gelişen endüstrilerden birisi olmuş, Türk sanayisinin gelişmesine öncülük etmiştir.

Tekstil endüstrisi, geçmişte gelişmiş ülkelerin sanayileşmelerini başarmalarını sağlarken, günümüzde de gelişmekte olan ülkelerin ihracata dayalı sanayileşmelerini sağlama yolunda önemli rol oynamaktadır. 1990'lı yıllardan sonra iktisat politikalarında artan biçimde etkinliğini hissettiren liberalizm ve bunun yanında tüm ülkeleri etkiyen küreselleşme olgusu, dünya ticaretini ve özellikle tekstil ve hazır giyim ürünlerinin uluslararası ticaretini önemli ölçüde etkilemektedir (Çoban ve Kök, 2005: s. 71).

1980'li yıllarda Türkiye'nin ihracatındaki hızlı artışın temel kaynağı tekstil ve hazır giyim sanayileridir. 1980-1995 döneminde tekstil ve hazır giyimin toplam ihracat gelirindeki payı \% 27'den \% 40'a yükselmiştir. Söz konusu artışta daha etkili olan sektör hazır giyimdir. 1990'lı yılların ikinci yarısına doğru, tekstil ve hazır giyimin ihracat paylarındaki artış yavaşlamaya başlamışıtır. Bunun yanında 1990'lı yıllardan bu yana ihracatın GSMH'ye oranında da değişiklik olmamıştır. Bu durum o dönemde tekstil ve hazır giyime bağlı ihracat atışının maksimum düzeye ulaştığını ortaya koymaktadır (Eruygur,Özçelik ve Taymaz, 2004: 6-7).

1996 yılında yürürlüğe giren Gümrük Anlaşması sonrasında koordinasyonsuz bir biçimde endüstrinin yatırımlarındaki hızlı artışın sonucunda endüstride aşırı kapasite ortaya çıkmıştır. Öte yandan Euro'un Dolar karşısında değer kazanması ve Avrupa'da görülen durgunlukla birlikte kapasite kullanım oranlarının düşmesine bağlı olarak üretim maliyetlerindeki artış, Türk tekstil endüstrisini olumsuz olarak etkilemiştir (Tan, 2001: s. 9).

Türkiye' de tekstil endüstrisinin istihdam ve ihracata çok katkı sağlaması nedeniyle sosyo-ekonomik işlev bakımından önemli rolü olduğu açıktır. Tekstil endüstrisi ileriye ve geriye doğru bağlantılarının olması, dolayısıyla endüstride ortaya çıkabilecek herhangi bir olumsuzluğun diğer endüstrileri negatif biçimde etkileyebilecek olması nedeniyle büyük önem taşımaktadır. $\mathrm{Bu}$ endüstrinin ihmal edilmesi, kit ve sinırlı bir sermaye birikimine sahip olan ülke ekonomisinde ve dolayısıyla toplumda bir takım siyasi ve sosyal dengesizliklerin ortaya çıkmasına neden olacaktır.

1980'li yıllardan günümüze tekstil ve giyim sanayi ihracatının bileşiminde değişiklikler ortaya çıkmış, giyim sanayi ihracatındaki artış tekstile nispetle daha fazla gerçeklemiştir. Başka bir deyişle, tekstil endüstrisi ihracatında ortaya çıkan artış, (hazır) giyim sektörü kaynaklıdır (Uzay, 2005: 55-56).

Tekstil endüstrisi, Türkiye'nin ihracat gelirlerinin yanında istihdam imkânlarını arttırması nedeniyle ülke ekonomisi için büyük önem rol taşımaktadır. 1980'li yıllardan günümüze tekstil endüstrisi istihdamının toplam imalat sanayi istihdamı içindeki payı artmıştır. Günümüzde imalat sanayi istihdamının yaklaşık olarak 1/3'üu, bu endüstrice sağlanmaktadır. Bu 
oran, ülke istihdamı bakımından söz konusu endüstrinin çok önemli olduğunu ortaya koymaktadır.

Türk endüstrisi için en önemli pazar $\mathrm{AB}$ 'dir. Genel olarak endüstri ihracatının yaklaşık \% 65'i bu piyasayadır. Tekstil endüstrisi için AB'nin en önemli pazar olmasının nedenlerini coğrafi yakınlık, AB'ye gümrüksüz ulaşım, göreceli düşük ücret düzeyi, AB'nin kalitesi yüksek malları talep etmesi biçiminde sıralanabilir. Özellikle, talebin hızla karşılanmasının gerektiği durumlarda $\mathrm{AB}$ ülkelerine olan yakınlık ve buna bağlı olarak taşıma maliyetlerinin nispeten düşük olması Türkiye için önemli bir rekabet avantajını sağlamaktadır (Uzay, 2005: 57-58). Günümüzde tekstil endüstrisinin Türkiye imalat sanayii içinde istihdamda, üretimde ve ihracatta önemli payı devam etmektedir.

Uluslararası ticaret tasnifinde genel anlamıyla tekstil endüstrisi üç ana başlık altında ele alınmaktadır. Tekstil elyafları ve bunların atıklarını içeren hammadde grubu olarak SITC 26 grubu, tekstil ipliği, dokuma, mensucat ve ilgili ürünleri kapsayan SITC 65 grubu ve geniş kapsamlı hazır giyim ve aksesuarlarının yer aldığı SITC 84 grubudur. Ülkelerin ticaret performansı karşılaştırmalarında genellikle imalat sanayi ürünleri olmaları nedeniyle SITC 65 ve SITC 84 grupları dikkate alınmaktadır. Söz konusu iki grup talep yapıları birbirlerinden farklı olmaları nedeniyle ayr1 analiz edilmektedir (Gönel 2001: 15-31). Bu çalışmada, Tablo 1'de görüldüğü gibi, SITC 84 grubunun endüstriler arası ticaret özelliği taşıması ve Türkiye'nin bu grupta yüksek düzeyde karşılaştırmalı üstünlük sağlaması nedeniyle temel olarak SITC 65 grubu (tekstil ürün grubu veya dokumac1lık) ele alınmaktadır. Tablo 1'de görüldüğü gibi, hazır giyim ve aksesuarlarının yer aldığg SITC 84 grubunun 1989-2009 aras1 EIT düzeyinin ortalamas1 \% 1'in altındadır. Başka bir deyiş̧le bu grubun ticaretinde endüstriler arası ticaret söz konusudur. Yine bu tabloya göre SITC $65^{\prime}$ in ya da dokumacilik grubunun toplam ticaretinde endüstri-içi ticaret düzeyinde önemli artışlar olduğu görülmektedir. Özellikle 1990'lı ve 2000'li yıllarda toplam dokumacıllk ticaretinde EİT eğilimi genel olarak artmıştır.

Tablo: 1 SITC 65 ve SITC 84 Ürün Grubunda GL Endüstri-içi Ticaret Endeksi

\begin{tabular}{lll}
\hline Yıl & SITC 65 & SITC 84 \\
\hline $\mathbf{1 9 8 9}$ & 0,361 & 0,004 \\
$\mathbf{1 9 9 0}$ & 0,565 & 0,009 \\
$\mathbf{1 9 9 1}$ & 0,546 & 0,015 \\
$\mathbf{1 9 9 2}$ & 0,608 & 0,014 \\
$\mathbf{1 9 9 3}$ & 0,780 & 0,021 \\
\hline
\end{tabular}




\begin{tabular}{lll}
\hline $\mathbf{1 9 9 4}$ & 0,672 & 0,015 \\
$\mathbf{1 9 9 5}$ & 0,835 & 0,016 \\
$\mathbf{1 9 9 6}$ & 0,830 & 0,049 \\
$\mathbf{1 9 9 7}$ & 0,819 & 0,067 \\
$\mathbf{1 9 9 8}$ & 0,790 & 0,066 \\
$\mathbf{1 9 9 9}$ & 0,708 & 0,062 \\
$\mathbf{2 0 0 0}$ & 0,733 & 0,078 \\
$\mathbf{2 0 0 1}$ & 0,655 & 0,069 \\
$\mathbf{2 0 0 2}$ & 0,802 & 0,068 \\
$\mathbf{2 0 0 3}$ & 0,791 & 0,081 \\
$\mathbf{2 0 0 4}$ & 0,787 & 0,110 \\
$\mathbf{2 0 0 5}$ & 0,772 & 0,125 \\
$\mathbf{2 0 0 6}$ & 0,764 & 0,167 \\
$\mathbf{2 0 0 7}$ & 0,804 & 0,203 \\
\hline $\mathbf{2 0 0 8}$ & 0,751 & 0,280 \\
\hline $\mathbf{2 0 0 9}$ & 0,759 & 0,313 \\
\hline Ortalama & 0,721 & 0,087 \\
\hline
\end{tabular}

Kaynak: 1989-2009 yılları için United Nations Statistics -Commodity Trade Statistics Database, http://comtrade.un.org/db 'den yararlanılarak tarafimızdan hesaplanmıştır.

Tablo 2'de görüldüğü gibi, ağırlıklı olarak tekstil malzemelerinden yapılmış mefruşat (SITC 658), halı, kilim vb. yer döşemeleri (SITC 659), örme veya dokuma kadifeler (SITC 655) ve tül, işlemeler, kenar bordürleri, dantel vb. ürün grubu (SITC 656) alt ürün grupları EITT bakımından performansları düşüktür. Başka bir söyleyişle bu alt ürün gruplarında ticaretin tek yönlü olması anlamını taşır. Türkiye' de söz konusu tek yönlü ticaret ihracat lehinedir.

Öte yandan diğer alt ürün grupları ticaretinde EİT düzeyinin yüksek düzeyde olduğu, hatta bazı yıllarda tümüyle EİT yapısına sahip bir özellik taş1dığ gözlemlenmektedir. Diğer bir ifadeyle, söz konusu dönemde bu alt ürün gruplarının karşılaştırmalı üstünlükleri azalırken, EİT düzeyleri artmıştır. Böyle artan ve yüksek EİT düzeyi, dış ticarette uygulanan liberalizasyon politikası ve $\mathrm{AB}$ ile yapılan Gümrük Birliği anlaşması sonucunda ilgili ürün grubu ithalatının artması ve yerli üretimin ikame edilmesi biçiminde yorumlanabilmektedir. 
Tablo 2: Türk Tekstil Grubunda GL Endüstri-içi Ticaret Endeksi

\begin{tabular}{|c|c|c|c|c|c|c|c|c|c|c|}
\hline Yll & 651 & 652 & 653 & 654 & 655 & 656 & 657 & 658 & 659 & $\begin{array}{l}\text { Ortala } \\
\text { ma }\end{array}$ \\
\hline 1989 & 0,568 & 0,302 & 0,307 & 0,707 & 0,142 & 0,236 & 0,482 & 0,016 & 0,014 & 0,308 \\
\hline 1990 & 0,791 & 0,573 & 0,673 & 0,770 & 0,242 & 0,701 & 0,765 & 0,037 & 0,065 & 0,513 \\
\hline 1991 & 0,758 & 0,518 & 0,803 & 0,850 & 0,247 & 0,560 & 0,940 & 0,024 & 0,051 & 0,528 \\
\hline 1992 & 0,904 & 0,523 & 0,786 & 0,945 & 0,430 & 0,683 & 0,971 & 0,053 & 0,044 & 0,593 \\
\hline 1993 & 0,812 & 0,776 & 0,870 & 0,868 & 0,697 & 0,577 & 0,915 & 0,057 & 0,050 & 0,625 \\
\hline 1994 & 0,863 & 0,666 & 0,813 & 0,961 & 0,784 & 0,416 & 0,859 & 0,039 & 0,039 & 0,604 \\
\hline 1995 & 0,806 & 0,916 & 0,872 & 0,964 & 0,864 & 0,450 & 0,852 & 0,063 & 0,063 & 0,650 \\
\hline 1996 & 0,840 & 0,819 & 0,989 & 0,837 & 0,845 & 0,563 & 0,879 & 0,075 & 0,239 & 0,676 \\
\hline 1997 & 0,908 & 0,874 & 0,997 & 0,687 & 0,743 & 0,602 & 0,900 & 0,064 & 0,278 & 0,673 \\
\hline 1998 & 0,953 & 0,824 & 0,990 & 0,721 & 0,711 & 0,560 & 0,745 & 0,052 & 0,275 & 0,648 \\
\hline 1999 & 0,925 & 0,801 & 0,911 & 0,845 & 0,505 & 0,355 & 0,743 & 0,048 & 0,288 & 0,602 \\
\hline 2000 & 0,982 & 0,850 & 0,880 & 0,872 & 0,589 & 0,397 & 0,807 & 0,050 & 0,354 & 0,642 \\
\hline 2001 & 0,895 & 0,851 & 0,755 & 0,826 & 0,474 & 0,276 & 0,900 & 0,049 & 0,329 & 0,595 \\
\hline 2002 & 0,817 & 0,896 & 0,835 & 0,730 & 0,568 & 0,339 & 0,836 & 0,039 & 0,338 & 0,600 \\
\hline 2003 & 0,778 & 0,874 & 0,759 & 0,680 & 0,583 & 0,351 & 0,834 & 0,042 & 0,313 & 0,579 \\
\hline 2004 & 0,831 & 0,916 & 0,787 & 0,576 & 0,575 & 0,328 & 0,876 & 0,048 & 0,362 & 0,589 \\
\hline 2005 & 0,795 & 0,924 & 0,716 & 0,621 & 0,460 & 0,365 & 0,839 & 0,063 & 0,356 & 0,571 \\
\hline 2006 & 0,801 & 0,975 & 0,703 & 0,631 & 0,382 & 0,487 & 0,898 & 0,084 & 0,369 & 0,592 \\
\hline 2007 & 0,639 & 0,942 & 0,703 & 0,701 & 0,361 & 0,493 & 0,866 & 0,108 & 0,326 & 0,571 \\
\hline 2008 & 0,707 & 0,893 & 0,633 & 0,734 & 0,349 & 0,524 & 0,841 & 0,116 & 0,308 & 0,567 \\
\hline 2009 & 0,732 & 0,944 & 0,701 & 0,728 & 0,381 & 0,578 & 0,832 & 0,124 & 0,233 & 0,584 \\
\hline $\begin{array}{l}\text { Ortala } \\
\text { ma }\end{array}$ & 0,815 & 0,793 & 0,785 & 0,774 & 0,521 & 0,469 & 0,837 & 0,060 & 0,224 & 0,586 \\
\hline
\end{tabular}

Kaynak:1989-2009 yılları için United Nations Statistics -Commodity Trade Statistics Database, http://comtrade.un.org/db 'den yararlanılarak tarafimızdan hesaplanmıştır.

Tablo 3' te dokumacilık alt ürün gruplarının hesaplanan $\mathrm{P}_{\mathrm{x}} / \mathrm{P}_{\mathrm{m}}$ değerlerinin ortalaması biçiminde gösterilmiştir. Tablo 3 'te görüldüğü üzere, SITC 65 mal grubunda 1989-1997 döneminde dikey mal farklılaşma durumu ortaya çıkarken, 1997-2009 arasında bu mal grubunda yatay mal farklılaşma söz konusudur. Elde edilen bulgular 1şığında, 1997 yılına kadar tekstil endüstrisi ticaretinde EİT' nin payı yıllar itibarıyla artarken, daha çok düşük kalite DEİT' nin hâkim olduğu, 1997 sonrasında bu yapının değiştiği, söz konusu mal grubunda kalitenin arttığı veya kaliteli ürünlerin ihraç edildiği biçiminde yorumlanabilir. Başka bir ifadeyle, küreselleşmeyle birlikte artan rekabet ortamı ve özellikle 1996 yılında yürürlüğe giren Gümrük Birliği 
anlaşması sonrasında Türk tekstil firmalarının en önemli pazar olan AB'deki paylarını kaybetmemek için kaliteyi ve katma değeri arttırma çabaları, ArGe'ye yapılan harcamalar vb faktörler, bu yapının değişmesine yol açtı̆̆ 1 şeklinde düşünülebilir.

Tablo 3: Türk Tekstil Sektöründe Endüstri-içi Ticaretin Türü (Yatay/Dikey: Eşik \pm 0.25)

\begin{tabular}{llll}
\hline Yll & GL Endeks & $\mathbf{P x} / \mathbf{P m}$ & Türü \\
\hline $\mathbf{1 9 8 9}$ & 0,308 & 1,858 & DEITT \\
$\mathbf{1 9 9 0}$ & 0,513 & 1,529 & DEITT \\
$\mathbf{1 9 9 1}$ & 0,528 & 1,877 & DEITT \\
$\mathbf{1 9 9 2}$ & 0,593 & 1,798 & DEİT \\
$\mathbf{1 9 9 3}$ & 0,625 & 1,880 & DEITT \\
$\mathbf{1 9 9 4}$ & 0,604 & 2,040 & DEITT \\
$\mathbf{1 9 9 5}$ & 0,650 & 1,910 & DEITT \\
$\mathbf{1 9 9 6}$ & 0,676 & 1,370 & DEITT \\
$\mathbf{1 9 9 7}$ & 0,673 & 1,097 & YEITT \\
$\mathbf{1 9 9 8}$ & 0,648 & 1,091 & YEITT \\
$\mathbf{1 9 9 9}$ & 0,602 & 1,055 & YEITT \\
$\mathbf{2 0 0 0}$ & 0,642 & 1,112 & YEITT \\
$\mathbf{2 0 0 1}$ & 0,595 & 1,025 & YEITT \\
$\mathbf{2 0 0 2}$ & 0,600 & 1,056 & YEİT \\
$\mathbf{2 0 0 3}$ & 0,579 & 1,171 & YEIंT \\
$\mathbf{2 0 0 4}$ & 0,589 & 1,075 & YEITT \\
$\mathbf{2 0 0 5}$ & 0,571 & 1,064 & YEITT \\
$\mathbf{2 0 0 6}$ & 0,592 & 1,052 & YEITT \\
$\mathbf{2 0 0 7}$ & 0,571 & 1,080 & YEITT \\
$\mathbf{2 0 0 8}$ & 0,567 & 1,118 & YEİT \\
$\mathbf{2 0 0 9}$ & 0,584 & 1,105 & YEITT \\
\hline
\end{tabular}

Kaynak: 1989-2009 yılları için United Nations Statistics -Commodity Trade Statistics Database, http://comtrade.un.org/db 'den yararlanılarak tarafimızdan

\section{Regresyon Analizi} hesaplanmıştır.

Genel olarak EITT'yi etkileyen faktörler ülkeye özgü belirleyiciler, endüstriye özgü belirleyiciler ve firmaya özgü belirleyiciler olmak üzere üç grupta incelenmektedir. Ülkeye özgü belirleyiciler kişi başına gelir, yabancı doğrudan yatırım, teslim uzaklığı vb. değişkenleri içermektedir. Endüstriye 
özgü belirleyiciler, ölçek ekonomileri, ürün farklılaştırması, eksik rekabet vb. durumlardır. Firmaya özgü belirleyiciler, teknik koşulları, firmanın stratejik davranışları gibi durumları kapsamaktadır. EİT'yi etkileyen faktörleri araştıran ampirik çalışmalarda ele alınan hipotezlerin farklı oldukları görülmektedir. Bu çalışmaların çoğu ürün farklılaştırması ve ölçek ekonomilerine ilişkin hipotezleri temel almaktadır (Tang, Liao ve Lan, 2009: 504-505). Öte yandan Türkiye'nin kendine özgü koşulları ve ilgili verilerin elde edilmesindeki zorluklar nedeniyle, bu çalışmada ülkeye özgü ve endüstriye özgü belirleyicileri temsil eden aşağıdaki üç değişken kullanılmıștır.

Kişi başına gelir: Genellikle, ülkelerin kişi başına düşen gelir farklılığı ne kadar düşükse, EİT oranının toplam ticarete oranı o derece yüksek olmaktadır (Lee, 1989: 346-58). Bu durum, tüketici zevkleri ve talep yapılarındaki benzerliklerin farklılaştııılmış mallar için piyasa oluşturdukları ve EITT düzeyini arttırdığı hipotezine bağlı olarak ifade edilmektedir. Tüketici zevklerindeki benzerlik aynı zamanda ölçek ekonomilerini kullanma firsatı sağlayarak ve ürün çeşitliliği nedeniyle söz konusu talebi karşılama imkânını arttırarak yerli ürünlerin yurtiçi ve yurtdışı pazarlarını (piyasalarını) genişletmektedir. Dolayısıyla bu hipotez, endüstri-içi ticaretin başlıca belirleyicisi olan ürün farklılaştırmasının talep yanıyla ilgilenmektedir (Tang, Liao ve Lan, 2009: 505). Modelde yer alan kişi başına düşen gelir değişkenin katsayısının pozitif olması beklenmektedir.

Kişi başına düşen gelir düzeyinin yükselmesi tüketicilerin birbirinden farklılaştırılmış ürünlere olan taleplerinin artmasına neden olmaktadır. Dolayısıyla farklılaştırılmış ürün ithalatının artması ve yerli üreticilerin iç ve dış talebin karşılanmasına yönelik farklılaştırılmış ürünler üretme çabası, neticede EITT düzeyinin yükselmesine önemli katkı sağlamaktadır (Küçükahmetoğu, 2002: 42).

Ölçek ekonomileri: Kavram olarak ölçek ekonomileri, bir firma veya endüstride üretim kapasitesi ölçeği genişletildikçe üretim artış oranının maliyetlerdeki artış oranından daha yüksek olmasını sağlayan etkileri ifade etmektedir (Seyidoğlu, 1999: 454). Ölçek ekonomileri, endüstri-içi ticaretin arz cephesinden başlica belirleyicisidir. (Clark, 1993: 333-334). Ortalama maliyetleri azaltmaya yönelik farklılaştırılmış malların çeşitliliğinde uzmanlaşma stratejisi, endüstri-içi ticarete yol açmaktadır. Çünkü büyük sabit maliyetlerin varlığ maliyeti azaltmaktadır (Tang, Liao ve Lan, 2009: 505). Modeldeki ölçek ekonomileri değişkenin katsayısının da pozitif olması beklenmektedir.

Artan getiri koşulları altında farklılaştırılmış ürünler üreten firmaların oluşturduğu endüstrilerde EITT oranının daha yüksek olması beklenir. Bu durum EİT ile ölçek ekonomiler arasında pozitif ilişki olacağı yönünde beklentiye yol açmıştır, fakat hemen hemen tüm ampirik çalışmalarda söz 
konusu parametreler arasında negatif ilişki olduğu ifade edilmektedir ${ }^{1}$. Teorik modeller EIT' nin kısmi ölçek ekonomilerinin varlığına bağlı olduğunu varsaymaktadır (Clark, 2010: 190). Helpman (1999) EİT uzmanlaşma derecesinin belirlenmesinde ölçek ekonomilerinin varlığının etkili olduğunu öne sürmektedir.

Clark (2010), düşük ölçek ekonomilerinin yüksek EİT oranlarıyla ilişkili olduğunu ifade ederken, bu ilişkinin kuvvetli olmadığını belirtmektedir. Yaptığı araştırmanın bulguları 1şı̆̆ında, tamamlanmamış (kısmi) ölçek ekonomilerinin EİT' nin belirlenmesindeki rolü üzerine gölge düştügünü savunmaktadır.

Doğrudan yabancı yatırım ile EİT arasındaki ilişki, doğrudan yabancı yatırımın türüne bağlı olarak şekillenmektedir. Pazar arayan doğrudan yabancı yatırımın ev sahibi ülkedeki pazar payını arttırmak ve ev sahibi ülkenin tüketicilerine ulaşmak amaçlarıyla ürettiği mallar, ana ülkenin tamamlayıcısı olması nedeniyle EİT düzeyinin azalmasına yol açmaktadır. Buna karşın maliyet avantajı arayan doğrudan yabancı yatırım, maliyetleri azaltmak ve ölçek ekonomilerini artırmak amacıyla üretimi birçok aşamaya bölerek gerçekleştirmektedir. Her bir aşamanın bir ülkede veya bir bölgede icra edilmesinin düzenlenmesi coğrafi ve mülkiyet bağlamında birtakım avantaj sağlamaktadır. Nihai ve yarı işlenmiş malların üretiminde uzmanlaşmayı hedefleyen emeğin bölüşülmesi aynı endüstride ise, EITT düzeyinin yükselmesine olumlu katkı sağlamaktadır (Fan ve Wang, 2008: 76-82). Dolayısıyla doğrudan yabancı yatırımın katsayısı pozitif veya negatif olacaktır.

Yapılan bir araştırmaya göre doğrudan yabancı yatırım, son yıllarda Doğu Asya'da Dikey EİT düzeyinin hızlı artışında önemli rol oynamaktadır. Dolayısıyla doğrudan yabancı yatırımın özellikle Dikey EIT üzerindeki etkisinin pozitif olması beklenmektedir (Fukao, Ishido ve Ito, 2003: ss. 468506).

Doğrudan yabancı yatırımın sabit maliyeti nispeten küçükse, firmalar çokuluslu şirket olmayı ve kendi ülkeleriyle yabancı ülkeler arasındaki faktör fiyatları farkından yararlanmayı tercih etmektedirler. Buna paralel olarak, ülkesiyle diğer ülke arasında ticari maliyetler ne derece düşükse, o kadar daha fazla dikey EİT düzeyi gerçekleşmesi beklenmektedir. Dolayısıyla, doğrudan yabancı yatırımın maliyetlerinin düşük olması, firmaların uluslararası dikey uzmanlaşmadan faydalanmalarına kolaylık sağlamakta ve bu durum dikey EİT'de artışla sonuçlanmaktadır (Fukao, Ishido ve Ito, 2003: ss. 468-506).

\footnotetext{
${ }^{1}$ Ayrıntılı bilgi için Balassa (1986), Balassa ve Bauwens (1987), Clark ve Stanley (2003) gibi kaynaklara bakınız.
} 
Ülkeye ve endüstriye özgü belirleyicileri birlikte ele alarak endüstriiçi ticaretin belirleyicilerini analiz etmek için oluşturulan model aşağıda verilmektedir:

$$
\text { LnIIT }=C+\beta_{1} \operatorname{LnPCI}+\beta_{2} \operatorname{LnSE}+\beta_{3} \operatorname{LnFDI}+U_{t}
$$

Modelde bağımlı değişken olarak kullanılan IIT Tekstil Sektörü endüstri-içi ticaret GL endeksini göstermektedir. Modelde bağımsız değişken biçiminde kullanılan PCI, Türkiye'de kişi başına düşen geliri ve SE KOBI'lerin GSYİH' ya katkılarını temsil etmektedir. Yabancı doğrudan yatırımı ölçmek için kullanılan FDI, söz konusu dönemde Türkiye'ye giren fiili yabanc1 doğrudan yatırımı ifade etmektedir. Hata terimini gösteren $U_{t}$, endüstri-içi ticareti etkileyen dışsal değişkenleri göstermektedir. Regresyon denklemi endüstri-içi ticaretin PCI, SE, FDI ve başka faktörlere bağlı olduğunu ifade etmektedir.

Tablo 4. Regresyon Analizi Sonuçları

\begin{tabular}{l|l|l|l}
\hline Bağımsız Değişkenler & Beklenen İşaret & \multicolumn{2}{|l}{ Bağımlı Değişken IIT } \\
\hline & & Katsayı & T-İstatistiği \\
Constant & & $-0,8288$ & $-2,7738$ \\
LnGDP & + & $0,6175^{*}$ & 7,3019 \\
LnSE & + & $0,5409^{* *}$ & 5,5664 \\
LnFDI & $+/-$ & $-0,1091^{*}$ & $-2,3713$ \\
$\mathrm{R}^{2}$ & & 0,8722 & \\
F-statistic & & 53,59 & \\
\hline
\end{tabular}

Not: $* *$ ve $*$ sırasıyla $\% 1 \quad$ ve $\% \quad 5$ seviyesinde istatistiksel anlamlılı̆̆ göstermektedir.

Tablo 4 regresyon analizinin sonucunu vermektedir. Bağımsız değişkenlerin katsayıları istatistikî olarak anlamlıdır. Modelin güvenirliği için White Testi ve Durbin Watson-d Testi yapılmıştır. Sonuçta regresyon modeli aşağıdaki gibidir:

LnIIT $=-0.8288+0.6175 \operatorname{LnPCI}+0.5409 \operatorname{LnSE}-0.1091 \operatorname{LnFDI}$

Analiz sonuçlarına göre, Türkiye'de kişi başına gelir \% 1 arttığında, Türk tekstil sektöründe endüstri-içi ticaret $\% 0.6175$ oranında artmaktadır. Ölçek ekonomilerinde \% 1 artış olduğunda tekstil sektöründe endüstri-içi ticaret \% 0. 5409 oranında yükselmektedir. Yabancı doğrudan yatırımlarda 
$\% 1$ oranında yükselme olduğunda, tekstil sektöründe yukarıdaki durumların aksine \% 0. 1091 oranında azalma söz konusudur.

Beklenildiği gibi kişi başına düşen gelirin katsayısı pozitif ve istatistikî olarak anlamlıdır. Başka bir ifadeyle, kişi başına düşen gelirdeki değişim Türk tekstil sektöründe endüstri-içi ticaret düzeyini aynı yönde etkilemektedir. Kişi başına düşen gelirdeki artış, Türkiye'de yerleşik kişilerin harcanabilir gelirini artırarak söz konusu kişilerin/tüketicilerin çok çeşit ürün talep etmelerine neden olacaktır. Öte yandan bir ülke, vatandaşlarının tüm ihtiyaçlarını karşılamada yetersiz kalabilmekte ve yurtiçinden karşılanmayan talep, ithalat biçiminde diğer ülkelerden karşılanabilmektedir. Bu durum tüm ülkeler için geçerlidir. Dolayısıyla bu karşılıklı talep genelde ülkenin EİT düzeyini, özelde ve bu araştırma kapsamında tekstil sektörünün EİT düzeyinin artışını teşvik etmektedir.

Analiz sonuçları, beklenildiği gibi, EİT' yi açılamada ölçek ekonomilerinin rolünü desteklemektedir. $\mathrm{Bu}$ durum, tekstil endüstrisindeki firmaların ortalama maliyetleri azaltma ve ürün çeşitliliğini arttırma stratejilerini uygulamada, üretimde etkin ölçeğe ulaşmada ve artan rekabet ortamında rekabet güçlerini arttırmada önemli adımlar attıklarını ortaya koymaktadır.

Endüstri-içi ticareti açıklamada yabancı doğrudan yatırımın rolüne ilişkin bulgular, onun varlığının tekstil sektöründe EİT düzeyini azaltmada etkili olduğunu göstermektedir. Analizin bu şekilde sonuç vermesi, sektöre gelen doğrudan yabancı yatırımların pazar arayan nitelik taşımasının neden olduğu düşünülmektedir. Diğer bir ifadeyle, bu tür yabancı yatırımların Türk tekstil sektörünü tercih etmeleri, ülkemizde emeğin özellikle $A B$ Bölgesine nazaran daha düşük maliyetli olmasına bağlı olduğu ifade edilebilir. Bununla birlikte Türk tekstil sektörüne yönelik doğrudan yabancı yatırımların seyri ve sektöre etkileri bu araştırmanın kapsamını aşmaktadır.

Öte yandan analizin sonuçlarının değerlendirilmesinde Türk tekstil endüstrisine yönelik doğrudan yabancı yatırımların sınırlı düzeyde olduğu göz önünde bulundurulmalıdır. Yabanc1 sermayeli firmaların \% 5-6'1 bu endüstride faaliyet göstermektedir (Uzay, 2005: 58).

\section{Sonuc}

Bu çalışma Türk tekstil sektöründeki EIT' yi etkileyen faktörleri ortaya koymaktadır. Oluşturulan modelde ülkeye özgü ve endüstriye özgü belirleyiciler olmak üzere iki tür hipotez kurulmuş ve test edilmiştir. Bağımsız değişkenler istatistikî olarak anlamlıdır.

Analizin bulgularına göre, kişi başına düşen gelir, EİT düzeyini kişi olumlu etkilemektedir. Dış ticaret ortaklarımızın çoğunluğunu gelişmiş̧ ülkeler, özellikle $A B$ üyesi ülkeler oluşturmaktadır. Ülkemizde kişi başına düşen gelirin nispeten daha fazla oranda artması, bu ülkelerle aramızdaki gelir farkını azaltacaktır. İki ülke arasındaki kişi başına gelirdeki farkı ne 
kadar azalırsa, bu ülkelerin toplam ticaretteki EİT oranı o derece artacaktır. $\mathrm{Bu}$ analiz literatürün çoğunluğuna paralel biçimde EİT ile ölçek ekonomiler arasında pozitif ilişki olduğunu göstermektedir. $\mathrm{Bu}$ durum endüstrideki firmaların üretimde etkin ölçeğe ulaşma yönünde önemli adımlar attıklarını ifade etmektedir. Tekstil endüstrisine yönelik doğrudan yabancı yatırımın EİT üzerindeki etkisi negatif yönlüdür. Öte yandan doğrudan yabancı yatırımın EITT üzerindeki etkisinin değerlendirilmesinde, doğrudan yabancı yatırımın sınırlı seviyede olduğu dikkate alınmalıdır.

Bu çalışma aynı zamanda Türk tekstil EİT' nin 1990' lı yılların ikinci yarısından itibaren türünün yatay endüstri-içi ticaret biçimine dönüştüğünü göstermektedir. Bu durum Türk tekstil firmalarının en önemli pazar olan AB'deki paylarını kaybetmemek için kaliteyi ve katma değeri arttırma çabalarının iyi netice verdiğini ortaya koymaktadır.

Türkiye için tekstil endüstrisi imalat sanayi ve sanayi üretimindeki pay, ihracat, ülke ekonomisine sağladığı net döviz girdisi, istihdam vb makroekonomik büyüklüklülere sağladığ 1 katkılar bakımından büyük önem taşımaktadır. Bunun yanında Türk tekstil endüstrisinin dünyada ve özellikle $\mathrm{AB}$ ülkelerindeki mevcut rekabet avantajını kaybetmemesi, ürün farklılaştırması temelinde katma değeri yüksek, moda ve markaya dayalı ürünler geliştirmesine ve pazar çeşitlendirmesine bağlidır.

Tekstil endüstrisi görülebilir gelecekte Türkiye ekonomisi için önemli rol oynamaya devam edecektir. Özellikle 2005 yılı sonrası ithalat kotalarının kaldırılmasıyla yoğunlaşan rekabet ortamında, Türkiye tekstil endüstrisinin mevcut pazar payını arttırarak sürdürebilmesi için üretkenlikte iyileşme kaydedilerek ve katma değeri yüksek ürünlerde uzmanlaşılması, ihracatta çeşitlendirmeye gidilmesi ve sınaî yapının zaman içinde dönüştürülmesi amaçlarına yönelik etkin bir teknolojik ve yasal altyapı ile desteklenmelidir.

\section{Kaynakça}

Aydın, A. (2008) "Endüstri-içi Ticaret ve Türkiye: Ülkeye Özgü Belirleyicilerin Tespitine Yönelik Bir Araştırma”, Marmara Üniversitesi İ.İ.B.F. Dergisi, Cilt XXV, Sayı:2, 881-921.

Balassa, B. (1963), “An Empirical Demonstration of Classical Comparative Cost Theory”, Review of Economics and Statitics, 45, 231-238.

Balassa, B. (1966), "Tariff Reductions and Trade in Manufactures among the Industrial Countries”, American Economic Review, 56 (3), 466-473. 
Balassa, B. (1986), "The Determinants of Intra-Industry Trade Specialization in the United States Trade", Oxford Economic Papers, 38, 220-233.

Balassa, B. ve Bauwens L. (1987), "Intra-Industry Specialization in a MultiCountry and Multi-Industry Framework”, Economic Journal, 97, 923-939.

Clark, D. P. (1993) "Recent Evidence on Determinants of Intra-Industry Trade", Review of World Economics, vol. 29, issue 2, 332-344.

Clark, D. P. ve Stanley D. L. (2003), "Determinants of Intraindustry Trade Between The United States and Industrial Nations", International Economic Journal, 17, 1-17.

Clark, D. P. (2010) "Scale Economies and Intra-Industry Trade", Economics Letters, 108, 190-192.

Çakmak, Ö. A. (2006) "Türkiye ile Almanya, İtalya, Fransa ve İngiltere Arasında İmalat Endüstrisinde Endüstri-içi Ticaretin Yapısı: 1991-2004", Ekonomik ve Sosyal Araştırmalar Dergisi, Cilt:3, Y11:2, Sayı:1, 30-47.

Çalışkan, Ö. (2010) "Türkiye-AB Ticaretinde Endüstri-içi Ticaret Olgusu, 1990-2007”, H.Ü. İktisadi ve İdari Bilimler Fakültesi Dergisi, Cilt 28, Sayı 2, 1-45.

Çepni, E. ve Köse, N. (2000), "Intra-Industry Trade Patterns of Turkey A Panel Study", METU International Conference on Economics IV, Ankara, September:13-16.

Çoban O. ve Kök R., (2005) "Türkiye Tekstil Endüstrisi ve Rekabet Gücü: AB Ülkeleriyle Karşılaştırmalı Bir Analiz Örneği, 1989-2001”, İktisat İşletme ve Finans, Mart, Y11: 20, 68-81.

Doğaner G. F. (2001a) "How Important is Intra-Industry Trade Between Turkey and its Trading Partners? A Comparison Between the European Union and Central Asia Turkic Republics", Russian and East European Finance and Trade, Vol.37, No:4, 61-76.

Doğaner G. F. (2001b), “Tekstil Sektöründe Endüstri-içi Ticaret”, Dış Ticaret Dergisi, Vol.21, 15-31. 
Erk, N. ve Tekgül, Y. (2001), "Ekonomik Entegrasyon ve Endüstri-içi Ticaret: Türkiye-AB Ülkeleri arasındaki Endüstri-içi Ticaretin Ölçülmesi ve Ticaret Tipinin Belirlenmesi”, METU International Conference on Economics V, Ankara, September:10-13.

Erlat G. ve Erlat H. (2003), "Measuring Intra-Industry and Marginal IntraIndustry Trade: The Case for Turkey", Emerging Markets Finance and Trade, Vol. 39, No:6, 5-38.

Eruygur O., Özçelik E. ve Taymaz E. (2004) “Tekstil ve Hazır Giyim Sanayilerinde Uluslararası Rekabet", İktisat İşletme ve Finans, Nisan, Yı1: 19, 5-23.

Fan A. ve Wang L. (2008) "An Empirical Analysis of Steel Intra-Industry Trade Between China and South Korea and its Determinants", Journal of Shandong University, vol.59, 76-82.

Greeaway, D. ve Milner C. (1986), The Economics of Intra-Industry Trade, Basil Blackwell, Oxford.

Greenaway D., Hine Robert C. ve Milner C. (1994), "Country-Specific Factors and Pattern of Horizontal and Vertical Intra-Industry Trade in the UK”, Weltwirtschaftliches Archiv, 130 (1), 77-100.

Greenaway D., Hine R. C. ve Milner C. (1995), "Vertical and Horizontal Intra-Industry Trade: A Cross Industry Analysis for the United Kingdom", The Economic Jounal, 105, 1505-1518.

Greenaway D. ve Torstensson J. (1997), "Bact to Future: Taking Stock on Intra-Industry Trade”, Weltwirtschaftliches Archiv, 133 (2), 249-269.

Grubel, H. G. (1967), "Intra-Industry Specialization and the Pattern of Trade", The Canadian Journal of Economics and Political Science, 33 (3), 374-388.

Grubel H. G. ve Lloyd, P. J. (1971), "The Empirical Measurement of IntraIndustry Trade", Economic Record, Vol. 47, Issue 4, 494-517. 
Helpman, E. (1981), "International Trade in the Presence of Product Differentiation, Economies of Scales and Monopolistic Competition: A Chamberlin-Heckscher-Ohlin Approach", Journal of Political Economy, 92, 451-471.

Helpman, E. (1999), "The Structure of Foreign Trade", Journal of Economic Perspectives, 13, 124-144.

Kaya, A. A. ve Atış A. G.,(2007), "Türkiye Kimya Sanayi Endüstri İçi Ticaretinin Statik ve Dinamik Analizi: Avrupa Birliği Üye ve Aday Ülkeleri, Rusya Federasyonu, Ukrayna ve Çin”, Ege Akademik Bakış, 7 (1), 251-291.

Krugman, P. R. (1981), "Intraindustry Specialization and the Gains from Trade”, The Journal of Political Economy, Vol.89, No:5 October: 959-973.

Krugman, P. R. (1979), "Increasing Returns, Monopolistic Competition and International Trade", Journal of International Economics, Vol. 9, 469-479.

Küçükahmetoğlu O. (2002), "Endüstri-içi Ticaret ve Türkiye", İktisat İşletme ve Finans, Ocak, Y11: 17, Sayı: 190, 34-50.

Kyoji F., Hikari I. ve Keiko Ito, (2003), "Vertical Intra-industry trade and foreign direct investment in East Asia", Journal of The Japanese and International Economies, 17,468-506.

Lancaster, K. J. (1980), "Intra-Industry Trade under Perfect Monopolistic Competition”, Journal of International Economics, Vol. 10, 151-175.

Lee S. Y., (1989), "A Study of the Determinants of Intra-Industry Trade Among the Pasific Basin Countries", Review of World Economics, vol.125, issue 2, 346-358.

RiverBatız, L. A. ve Oliva, M. A. (2003), International Trade: Theory, Strategies, and Evidence, Oxford University Press.

Seyidoğlu H. (1999), Ekonomik Terimler Ansiklopedik Sözlük, Güzem Can Yayınları, 2. Baskı, İstanbul.

Şimşek, N. (2005), “Türkiye'nin Yatay ve Dikey Endüstri-içi Dış Ticareti”, D.E.Ü.İ.İ.B.F. Dergisi, Cilt 20, Sayı:1, 43-62. 
Tan, B. (2001), Overview of the Turkish Textile and Apparel Industry, Harvard Center for Textile \& Apparel Research, Cambridge.

Tang Y., Liao Y. ve Lan Y. (2009), "An Empirical Study on the Determinants of Intra-Industry Trade in Chinese Manufacturing", 2009 Second International Conference on Future Information Technology and Manufacturing, 503-506.

Uzay, N. (2005), "Değişen Dünya Koşullarında Türkiye'de Tekstil ve Hazır Giyim Sektörünün Geleceği”, İktisat İşletme ve Finans, Mart, Yı1: 20, 54-67.

Verdoorn, P. J. (1960), “The Intra-Bloc Trade of Benelux”, E.A.G. Robinson (Ed.), Economic Consequences of the Size of Nations içinde, Macmillan-Co. Ltd., London, 291-329.

Yenilmez F. ve Kutlu E. (2005)," Türkiye ile AB Ülkeleri Arasındaki Endüstri İçi Ticaretin Önemi" İktisat, İşletme ve Finans Dergisi, Sayı: 229, Nisan, 45-64.

Yılmaz, Ş. E., (1992), Dış Ticaret Kuramlarının Evrimi, Gazi Üniv. Yayın No: 178, İ.İ.B.F. Yayın No: 57, Ankara. 